\author{
JAŚMINA KORCZAK-SIEDLECKA \\ Instytut Historii PAN, Warszawa
}

\title{
CZY CHŁOP MIAŁ HONOR? ZASTOSOWANIE KATEGORII HONORU W BADANIACH NAD SPOŁECZEŃSTWEM NOWOŻYTNYM
}

\begin{abstract}
Abstrakt: Artykuł szuka odpowiedzi na pytania o znaczenie honoru i możliwe sposoby jego interpretacji, a także o przydatność tej kategorii w badaniach historycznych. Refleksje teoretyczne zostały uzupełnione analizą wiejskich ksiąg sądowych $\mathrm{z}$ terenu Mierzei Wiślanej z przełomu XVI/XVII w., dowodzącą kluczowej roli honoru w ówczesnych społecznościach chłopskich.
\end{abstract}

Słowa kluczowe: honor, cześć, chłopi, społeczeństwo nowożytne, hierarchia wartości.
Abstract: The article seeks to answer the questions about the meaning of honour and its possible interpretations, together with that about the usefulness of this category in historical studies. The theoretical reflections are reinforced with an analysis of village court registers from the area of the Vistula Spit at the turn of the seventeenth century which proves the key role of honour within contemporary peasant communities.

Keywords: honour, dignity, peasants, early modern society, hierarchy of values.

Nie masz Miasteczka, Pałacu, Kościoła, Nie masz wśi, domu, y Klasztoru, zgoła. Nie masz pośiadki, karczmy ani Dworu, Gdźieby nie miano coś za punkt honoru.

Antoni Sebastian Dembowski, Punkt honoru

Czy chłop miał honor? Czy miał go rzemieślnik, karczmarz, czy miała go służąca? Czy posiadanie honoru było zjawiskiem powszechnym w nowożytnym społeczeństwie, jak sugeruje autor powyższego cytatu? Kategoria honoru od lat zajmuje ważną pozycję w badaniach zachodnioeuropejskich 
historyków, jednak wciąż nie znalazła uznania w polskiej historiografii. Co więcej, wśród wielu badaczy wciąż pokutuje wizja honoru jako wartości moralnej (ahistorycznej) bądź jako wyróżnika stanu szlacheckiego. Niniejszy artykuł ma na celu przybliżenie pojęcia honoru w europejskim społeczeństwie epoki nowożytnej, z odwołaniem do klasycznych teorii na ten temat z zakresu filozofii, socjologii i antropologii kulturowej. Przedstawione zostaną różne sposoby ujęcia kategorii honoru w badaniach nad gospodarką, płcią kulturową, funkcjonowaniem prawa, przestępczością, komunikacją i przemocą. Refleksje teoretyczne zostaną uzupełnione w drugiej części tekstu badaniami empirycznymi przeprowadzonymi na księgach sądowych wsi na Mierzei Wiślanej z przełomu XVI/XVII w. Analiza źródłowa potwierdzi tezę o kluczowym znaczeniu honoru, także wśród chłopów epoki nowożytnej.

$\mathrm{Na}$ początku należałoby wspomnieć o pewnej trudności natury językowej. Większość przywołanych w artykule prac bazowała na źródłach w języku niemieckim, w którym słowo określające honor - Ehre (od starowysokoniem. êra) jest używane niezmiennie od wczesnego średniowiecza do czasów obecnych. W języku polskim występuje kilka terminów, zmieniających swój zakres znaczeniowy w ciągu wieków. Słowo honor (łac. honor, honoris) pojawiło się w polszczyźnie dopiero pod koniec XVI w. i przez następne dziesięciolecia było stosowane głównie w kontekście sprawowanych urzędów. Nowożytne słowniki jako tłumaczenie z niemieckiego lub łaciny podają najczęściej polskie cześć (od psł. čbstb), ale również chwała, poczciwość, uczciwość, zacność. Przymiotnik określający osobę honorową (niem. ehrlich, łac. honestus) tłumaczono jako poczciwy, poczesny, uczciwy, cnotliwy ${ }^{1}$. W Nowym Dykcyonarzu Michała Abrahama Trotza z 1779 r. wyraz honor jest już jedynym polskim tłumaczeniem niemieckiego i francuskiego odpowiednika². Z czasem cześć wypierana przez honor zaczęła nieść inne konotacje znaczeniowe. W każdym razie w polskojęzycznych źródłach wczesnej nowożytności czytelnik napotka wielość różnych określeń tego samego zjawiska, co może utrudniać przeprowadzenie analizy. Nawet w języku angielskim, gdzie funkcjonowało jedno, dominujące określenie honoru, badacz znajduje liczne opisy sytuacji honorowych bez stosowania terminu honour. Jego brak nie oznacza

${ }^{1}$ J. Mączyński, Lexicon Latino Polonicum, [Królewiec] 1564, k. 157; J. Ernesti, Forytarz języka polskiego, [Świdnica] 1690, s. 187-189; A. Calagius, Synonyma Latina Vocum, [Wrocław] 1579, s. 141-146; N. Volckmar, Dictionarium Trium Linguarum Latine, Germanice Et Polonice, [Gdańsk] 1605, s. 402; A. Faber, Celaryus Polski, [Brzeg ca 1730], s. 48.

2 M.A. Trotz, Nowy Dykcyonarz to iest mownik polsko-niemiecko-francuski, [Lipsk] 1779, s. 471. 
wszakże nieobecności zjawiska ${ }^{3}$. W niniejszym artykule, dla jasności wywodu, będę używać wyłącznie słowa honor, nawet gdy w pewnych połączeniach przyjęły się jego synonimy. Zastosowanie jednego terminu wiąże się z założeniem wywodu, że, niezależnie od zmieniających się kontekstów i określeń, mamy do czynienia z jednym zagadnieniem.

W rozważaniach na temat honoru należałoby na początek zadać pytanie o jego historyczność. Możemy uznać, że honor jest kategorią moralną, która nie ulega zmianom historycznym, albo założyć, że pojęcie to zmienia się wraz ze społeczeństwem i jest zależne od kontekstu kulturowego. W pierwszym wypadku honor będzie rozumiany jako wewnętrzna wartość człowieka, w drugim nacisk będzie kładziony głównie na wymiar „zewnętrzny” (społeczno-kulturowy) ${ }^{4}$. Artur Schopenhauer w Parergach i paralipomenach poświęcił cały rozdział analizie owego „zewnętrznego" wymiaru honoru. Jest on według niego „cudzą opinią o naszej wartości” wraz z „obawą, jaką odczuwamy przed tą opinią"5. Człowiek jako istota społeczna chce sprostać oczekiwaniom innych, by mieć udział we wspólnych korzyściach, dlatego musi stosować się do ogólnie przyjętych reguł postępowania. Nie chodzi jednak o to, jak pisze Schopenhauer, „Czy spełnia te wymogi we własnym mniemaniu, lecz o to, jakie mnie-

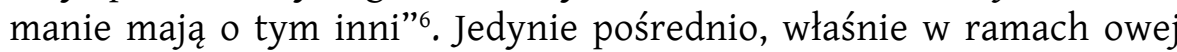
obawy, honor może oddziaływać na postępowanie jednostki, jednak sam w sobie kategorią moralną nie jest. Co więcej, filozof podkreśla, że ciągłe staranie się o dobrą opinię ma negatywny wpływ na wewnętrzny spokój jednostki i jej poczucie niezależności ${ }^{7}$. Niemniej jednak honor jest jednym z najważniejszych elementów tożsamości człowieka. Ta, według Schopenhauera, obejmuje: a) osobowość, w tym charakter, inteligencję, wykształcenie itp. (poziom wewnętrzny); b) stan posiadania (poziom pośredni); c) cudzą opinię (poziom zewnętrzny). Ostatnią kategorię dzieli na następne trzy części: honor, rangę i sławę. Honor czyli „dobre imię” jest według filozofa kategorią uniwersalną, która jest i powinna być bliska każdemu człowiekowi. Co innego, jeśli chodzi o pozostałe dwie rangę (pozycję), która odnosi się tylko do tych, którzy służą państwu, oraz sławę, która powinna wyróżniać jedynie wybranych ${ }^{8}$. Podział ten

${ }^{3}$ C.L. Barber, The Idea of Honour in the English Drama 1591-1700, Göteborg 1957, s. 32.

${ }^{4} \mathrm{H}$. Wellmann, Der historische Begriff der „Ehre” - sprachwissenschaftlich untersucht, w: Ehrkonzepte in der Frühen Neuzeit. Identitäten und Abgrenzungen, red. S. Backmann, H.-J. Künast, S. Ullmann, B.A. Tlusty, Berlin 1998 (Colloquia Augustana, t. 8), s. 28.

${ }^{5}$ A. Schopenhauer, W poszukiwaniu mądrości życia, Warszawa 2002, s. 454.

${ }^{6}$ Ibidem.

7 Ibidem, s. 442.

${ }^{8}$ Ibidem, s. 401. 
jest interesujący pod względem dostępności kategorii honoru dla różnych klas społecznych (do czego jeszcze wrócimy).

Adam Mahrburg w artykule dla Wielkiej powszechnej encyklopedii ilustrowanej z 1902 r. również odróżnił honor od wartości moralnej, choć zaproponował inną kategoryzację. W znaczeniu przedmiotowym jest to „dobre imię", które jednostka może zdobyć poprzez stosowanie się do norm społecznych, a więc dokładnie to, o czym pisał Schopenhauer. Mahrburg dodaje tu jeszcze wszystkie zewnętrzne oznaki uznania, w tym symbole sprawowanych urzędów. Znaczenie podmiotowe jest ściślej związane z przynależnością do grupy społecznej, na poziomie bardziej "wewnętrznym”, lecz wciąż niemającym nic wspólnego z moralnością jednostki: "Jest to zatem poczucie w sobie, nie godności moralnej w najogólniejszem znaczeniu, lecz godności stanowej, korporacyjnej". Dla rozumienia honoru jako kategorii etycznej Mahrburg proponuje inny termin - cześć - który w znaczeniu podmiotowym jest „poczuciem i uszanowaniem w sobie godności moralnej człowieka w ogóle”, natomiast w znaczeniu przedmiotowym oznacza „uznanie czyjejkolwiek wartości moralnej i okazywanie tego słowem lub postępowaniem". Dla poczucia czci nieistotna jest przynależność do danej grupy społecznej, sprawowane godności, reputacja. Tu postępowaniem człowieka nie kieruje staranie się o przychylną opinię zbiorowości, lecz własne sumienie ${ }^{9}$.

Koncepcja honoru była następnie rozwijana w klasycznych pracach socjologicznych. Według Georga Simmla honor jako czynnik częściowo „wewnętrzny”, częściowo „zewnętrzny” był gwarancją prawidłowego postępowania członka grupy w sytuacji, gdy prawo nie mogło tego sankcjonować, a moralność mogła być zawodna ${ }^{10}$. Dla Maxa Webera honor był cechą charakterystyczną społeczeństwa feudalnego, gwarantem trwałości relacji wasalnych. Był ściśle związany z pojęciem stanu, a więc z określonym sposobem życia, modelem wychowania, możliwościami zarobkowymi, prestiżem wynikającym z pochodzenia ${ }^{11}$. Norbert Elias włączył ideę honoru do swojej tezy o procesie cywilizowania się europejskiego społeczeństwa. Centrum cywilizacji miał być dwór absolutystycznego

9 A. Mahrburg, Honor, w: Wielka encyklopedia powszechna ilustrowana, seria 1, t. 29-30, Warszawa 1902, s. 322.

10 G. Simmel, Pisma socjologiczne, oprac. H.-J. Dahme, O. Rammstedt, Warszawa 2008, s. 338-339.

${ }_{11}$ M. Weber, Gospodarka i społeczeństwo. Zarys socjologii rozumiejacej, Warszawa 2002 (oryg. niem. 1922), s. 675-678. Choć Weber ściśle wiąże honor ze stanem szlacheckim, nie odmawia go jednak grupom marginesu społecznego: „Nawet najbardziej pogardzany lud pariasów kultywuje nadal w pewien sposób, swoistą zarówno dla etnicznych, jak i stanowych wspólnot, wiarę we własny szczególny honor", ibidem, s. 677. 
króla, na którym wykształcały się formy towarzyskie i sposoby postępowania dla całego społeczeństwa. Honor obejmował kod zachowania, styl życia, strój, architekturę - słowem wszystko to, co wyrażało przynależność do elit. Świadczył on o społecznej wartości dworzanina i jego szansach na zdobycie stanowiska ${ }^{12}$. Mimo późniejszej krytyki tych założeń, należy docenić ukazanie fundamentalnej roli honoru w kształtowaniu zachowań i jego komponenty, takie jak strój. Późniejsze badania pokazały jednak, że honor zaskakująco łatwo dopasowuje się do różnych konstelacji historyczno-kulturowych i nie można go zredukować do funkcji budowania władzy ${ }^{13}$.

Zmiana w postrzeganiu honoru nastąpiła w drugiej połowie XX w. na gruncie antropologii kulturowej. Szczególnie zasłużył się tu Pierre Bourdieu, który, badając wiejskie środowisko Kabylów w Północnej Afryce, zauważył nadrzędny wpływ honoru na relacje społeczne. Żyjąc w małej, tradycyjnej społeczności, jednostka jest całkowicie zależna od pozostałych jej członków, którzy określają jej miejsce we wspólnocie. Każdy członek takiej zbiorowości jest przez nią stale kontrolowany i poddawany ocenie. Jakiekolwiek niezastosowanie się do norm społecznych może skończyć się wyrzuceniem go z grupy, czyli ograniczeniem dostępu do zasobów, co może realnie przekładać się na jego możliwości przeżycia. Wobec tego jednostka stale uważa na to, jakie zdanie mają na jej temat inni, i to do tego stopnia, że staje się to także dla niej prawdą o sobie samej. Tożsamość człowieka jest odtąd nierozerwalnie związana z jego reputacją $\mathrm{z}$ honorem ${ }^{14}$. Bourdieu połączył $\mathrm{w}$ ten sposób wymiary „wewnętrzny” $\mathrm{z}$,zewnętrznym”, które były wcześniej traktowane rozdzielnie. W kabylskich wioskach rywalizujące ze sobą jednostki bądź grupy, by zdyskredytować przeciwną stronę, wystawiają na szwank jej honor, najczęściej po prostu obrzucając ją obraźliwymi słowami i pomówieniami. Każda taka sytuacja wymaga odpowiedzi drugiej strony, bierność bowiem oznacza przyznanie racji oszczercy i zgodę na przedmiotowe traktowanie

12 N. Elias, Die höfische Gesellschaft. Untersuchungen zur Soziologie des Königtums und der höfischen Aristokratie mit einer Einleitung. Soziologie und Geschichtswissenschaft, Darmstadt, Neuwied 1977, s. 157, 145, za: Verletzte Ehre. Ehrkonflike in Gesellschaften des Mittelalters und der Frühen Neuzeit, red. K. Schreiner, G. Schwerhoff, Köln 1995, s. 7.

${ }^{13}$ M. Dinges, Die Ehre als Thema der Stadtgeschichte. Eine Semantik im übergang vom Ancien Régime zur Moderne, „Zeitschrift für Historische Forschung” 16, 1989, 4, s. 414-416.

14 „The point of honour is the basis of the moral code of an individual who sees himself always through the eyes of others, who has need of others for his existence, because the image he has of himself is indistinguishable from that presented to him by other people", P. Bourdieu, The Sentiment of Honour in Kabyle Society, w: Honour and Shame. The Values of Mediterranean Society, red. J.G. Peristany, Chicago 1970, s. 211. 
własnej osoby. Prowadzi to do sytuacji ciągłych wyzwań i odpowiedzi na nie, co niekiedy przeradza się w wieloletnie wendetty. Istotną rolę odgrywa przy tym solidarność grupowa, jednostka zawsze bowiem działa w ramach zbiorowości, czy będzie to rodzina, grupa zawodowa, czy plemię $e^{15}$. Obserwacje te doprowadziły Bourdieu do tezy, że honor można rozpatrywać jako kapitał społeczny, który, tak jak kapitał ekonomiczny, można kumulować i nim obracać16.

W czasie gdy Bourdieu publikował The Sentiment of Honour in Kabyle Society, w krajach Europy Zachodniej trwała dyskusja o przejęciu modeli teoretycznych nauk społecznych przez historyków, rosła krytyka teorii modernizacji, zadawano pytania o historyczność i uniwersalność pojęć takich jak płeć, pojawiały się studia mikrohistoryczne. Stąd blisko już było do zastosowania tez Bourdieu na temat honoru w badaniach nad dawnym społeczeństwem europejskim. Historycy, którzy zajęli się życiem codziennym bądź pospolitą przestępczością, zauważyli pewną prawidłowość w codziennych konfliktach sąsiedzkich, karczemnych bójkach, wojenkach czeladników rzemieślniczych. Badając głównie miejskie księgi sądowe, zwrócili uwagę na niezliczone skargi na obraźliwe gesty i obrzucanie się wyzwiskami. Kluczem do zrozumienia tego typu aktów agresji był honor. Honor, który przestał być już rozpatrywany jako kategoria moralności, a zaczął być traktowany jako kod zachowania, kompleksowy system reguł, medium społecznej interakcji, który w zależności od czasu, kultury, grupy społecznej może przyjmować różne, a nawet sprzeczne formy ${ }^{17}$.

Przyglądając się życiu codziennemu epoki przednowoczesnej, nie można nie zauważyć niezwykłej wrażliwości ówczesnych na punkcie honoru. Jak pisał Schopenhauer: ,jest rzeczą zdumiewającą, do jakiego stopnia drażni niechybnie, a często głęboko rani człowieka każde zadraśnięcie jego ambicji, w jakikolwiek sposób, w jakimkolwiek stopniu i pod jakimkolwiek względem, każde lekceważenie, każde poniżenie, każdy brak szacunku"18. Lekkie popchnięcie w tańcu lub niewinne przekomarzanie się mogło zostać odebrane jako atak na honor i przerodzić się w poważny konflikt ${ }^{19}$. Obrażenie mogło naruszyć integralność cielesną przy różnych agresywnych gestach, na przykład zerwaniu nakrycia głowy, dlatego odpowiedź na takie przekroczenie granic była przekonywająca

15 Ibidem, s. 199-201.

16 Verletzte Ehre, s. 10.

17 Ibidem, s. 9-10.

18 A. Schopenhauer, op. cit., s. 442.

${ }_{19}$ K. Simon-Muscheid, Gewalt und Ehre im spätmittelalterlichen Handwerk am Beispiel Basels, „Zeitschrift für Historische Forschung” 18, 1991, 1, s. 18. 
również na płaszczyźnie fizycznej ${ }^{20}$. Dla honoru ludzie byli skłonni zaryzykować swoje życie w bójce. Jak pisał Monteskiusz, analizując system prawny Franków i pochodzenie zasad honorowych: „Ustaliła się zasada, że, skoro komuś zadano łgarstwo, trzeba się było bić"21. Bardzo częstym zjawiskiem była też agresja werbalna. Księgi sądowe zapełnione są skargami z powodu obrzucenia kogoś wyzwiskami. W niemieckim kręgu językowym w XVI-XVII w. powtarza się dosłownie kilka obelg, których używano, by nadwyrężyć honor drugiej strony. Były to: „szelma” (czyli człowiek niehonorowy), „złodziej” i „kurwa” oraz kombinacje powyższych np. „złodziejska kurwa”, ewentualnie z dodaniem słowa „niehonorowy/a" lub innych poniżających określeń odnoszących się do świata zwierząt, mniejszości etnicznych, religijnych itp. ${ }^{22}$ Takie znieważenia odbierano jako niezwykle bolesne i traktowano równie poważnie jak przemoc fizyczną. Dlaczego bycie nazwanym szelmą było aż tak dotkliwe? Przede wszystkim należy przypomnieć, że wciąż obracamy się w kręgu kultury ustnej, gdzie słowo mówione miało niezwykłą siłę oddziaływania. Wyzwisko nie było tylko „brzydkim słowem”, bo słowo mogło zmieniać rzeczywistość. Zakwestionować honor mogły nie tylko obelgi, lecz także wszelkiego rodzaju groźby, plotki, posądzenia. Zawsze jednak chodziło o podważenie społecznego zaufania.

Jeśli pod pojęciem honoru będziemy rozumieć społeczną i ekonomiczną „wiarygodność kredytową" w stosunkach zawodowych, handlowych i innych relacjach społeczno-ekonomicznych, nadszarpnięcie jej stanie się najprostszym sposobem pozbycia się konkurencji ${ }^{23}$. Popadnięcie $\mathrm{w}$ niesławę szło $\mathrm{w}$ parze $\mathrm{z}$ utratą zarobków, miejsca pracy, mieszkania, szansy na korzystne małżeństwo - honor miał więc wartość ekonomiczną ${ }^{24}$. Założenie to wpisuje się w nowy kierunek badań nad nowożytną gospodarką, który zakłada, że nie maksymalizacja zysków, ale dbałość o relacje międzyludzkie i zasoby niematerialne jak zaufanie, honor, lojalność decydowały o sukcesie ekonomicznym ${ }^{25}$. Określenie

${ }^{20}$ H. de Waardt, Ehrenhändel, Gewalt und Liminalität. Ein Konzeptualiesierungsvorschlag, w: Verletzte Ehre, s. 318.

${ }^{21}$ Monteskiusz, O duchu praw, Warszawa 1927.

${ }^{22}$ K.-S. Kramer, Hohnsprake, Wrakworte, Nachschnack und Ungebühr. Ehrenhändel in holsteinischen Quellen, „Kieler Blätter zur Volkskunde” 16, 1984, s. 60-61.

${ }^{23}$ K. Simon-Muscheid, op. cit., s. 2-3.

24 A. Farge, Rodziny. Honor i sekret, w: Historia życia prywatnego, t. 3: Od renesansu do oświecenia, red. R. Chartier, red. wyd. pol. A. Łoś, Wrocław-Warszawa-Kraków 2005, s. 679 .

${ }^{25}$ Die Ökonomie sozialer Beziehungen. Ressourcenbewirtschaftung als Geben, Nehmen, Investieren, Verschwenden, Haushalten, Horten, Vererben, Schulden, red. G. Jancke, D. Schläppi, Stuttgart 2015. 
„niehonorowy” zawierało wiele znaczeń w zależności od kontekstu mógł być to nieuczciwy handlarz, niefachowy rzemieślnik, mężczyzna, który ożenił się z kobietą niższego stanu; słowem jednostka niedostosowująca się do etosu właściwej sobie grupy. Etos wyraża bowiem zarówno grupowe, jak i jednostkowe pragnienie realizowania wyznawanych wartości w życiu codziennym ${ }^{26}$. Nieprzypadkowo większość znieważeń miała miejsce w obecności osób trzecich, a sprawa stawała się jeszcze poważniejsza, gdy doszło do tego w miejscu publicznym obrażony popadał wtedy w krytyczny stan niepewnego statusu społecznego. Julian Pitt-Rivers zaryzykował tezę, że bez świadków nie było dyshonoru ${ }^{27}$. Wątpliwość wysunięta wobec jednej osoby przekształcała cały układ między dotąd równymi sobie i szanującymi się jednostkami ${ }^{28}$. Niewskazane było mieć kogoś takiego za sąsiada, nie godziło się mieć niehonorową osobę w rodzinie, ryzykownie było robić z kimś takim interesy. Dlatego też każda obraza wymagała odpowiedniej, szybkiej reakcji. Bierność mogła zostać zrozumiana jako potwierdzenie zarzutu. Spostrzeżenia te zgadzają się z ustaleniami Bourdieu, jednak historycy zwrócili uwage na pewien mankament $\mathrm{w}$ jego teorii o kapitale - honoru nie dało się kumulować tak jak dóbr materialnych, ponieważ podlegał on nieustannym wahaniom. Honor można było w każdej chwili stracić, by potem móc znów go odzyskać ${ }^{29}$. Powodowało to ciągłe zmiany w strefie wpływów ${ }^{30}$. Zasada zmienności odnosi się zresztą do relacji społecznych w ogóle, które nie powinny być rozumiane jako stabilne połączenia między jednostkami, lecz jako różne konstelacje, stale ulegające przekształceniom ${ }^{31}$. Płynność hierarchii społecznej wymagała nieustannego zabiegania o szacunek bliźniego, bo tylko on dawał gwarancję utrzymania należnego miejsca w zbiorowości ${ }^{32}$. Uznając koncepcję honoru „dynamicznego", można postawić tezę, że punkt honoru jest zdolnością jednostki do rzucania wyzwania i odpowiadania na nie. Przyjęcie wyzwania od osoby niższego stanu oznaczało utratę własnego honoru i odwrotnie - zgoda na pojedynek była wyrazem potwierdzenia równego „statusu honorowego".

${ }^{26}$ B. Fedyszak-Radziejowska, Etos pracy rolnika. Modele społeczne a rzeczywistość, Warszawa 1992, s. 27-29.

${ }^{27}$ J. Pitt-Rivers, Honour and Social Status, w: Honour and Shame, s. 27.

28 A. Farge, op. cit., s. 678.

29 Verletzte Ehre, s. 11.

${ }^{30}$ M. Dinges, Die Ehre als Thema der Stadtgeschichte, s. 421-422.

${ }^{31}$ G. Jancke, D. Schläppi, Einleitung. Ressourcen und eine Ökonomie sozialer Beziehungen, w: Die Ökonomie sozialer Beziehungen, s. 22.

32 A. Farge, op. cit., s. 677. 
Ciągłe powtarzanie schematu akcja-reakcja niesie za sobą rytualizację zachowań honorowych. Nie dotyczy to tylko sytuacji konfliktowych, schemat ten powtarza się też przy wymianie podarków lub pozdrowień, gdzie honor wymaga właściwej odpowiedzi. Bourdieu, opisując walki plemienne, wskazywał na ich powtarzalny przebieg - najpierw wymiana obraźliwych słów, a dopiero później użycie siły fizycznej ${ }^{33}$. Analogicznie wyglądało to w nowożytnej Europie, gdzie można dokładnie odtworzyć schemat typowej awantury w karczmie: od podważenia honoru, poprzez bijatykę, aż do tumultu ${ }^{34}$. Podobną rytualizację przejawiały szlacheckie zajazdy - na Wołyniu przed wszczęciem działania z użyciem przemocy należało publicznie ogłosić zamiar dokonania zemsty za obrazę ${ }^{35}$. Powyżej wspomniano już o powtarzalności obelżywych słów, co wiąże się z schematycznością wypowiedzi raniących honor. Mimo że na pierwszy rzut oka awantury opisane w nowożytnych źródłach wydają się być niepohamowanym wybuchem emocji, często były to sytuacje zaplanowane, o ustalonym przebiegu znanym obu stronom. Jest jeszcze jedna bardzo charakterystyczna cecha tego typu walk - rzadko prowadziły one do śmierci ${ }^{36}$. Nie chodziło bowiem o to, by zabić przeciwnika, lecz by go pozbawić honoru zdyskredytować w oczach społeczności i zademonstrować swoją przewagę.

Warto tu poruszyć problem koegzystencji dwóch systemów norm honor można rozpatrywać jako system kontroli społecznej konkurencyjny dla obowiązujących przepisów prawnych. W trakcie rozstrzygania sporów często dochodziło do sprzeczności norm. Już w XIV w. rady miejskie zabiegały o monopol na użycie przemocy i nie dopuszczały do prywatnej regulacji konfliktu jak zemsta czy samosąd. Dla sądu, którego nadrzędnym celem było zachowanie porządku w mieście, utrzymanie pokoju było ważniejsze niż walka o honor indywidualny, dlatego przez całą epokę nowożytną wciąż wiele konfliktów rozwiązywano prywatnie ${ }^{37}$. Jednocześnie również $\mathrm{w}$ oficjalnej praktyce prawnej honor odgrywał istotną rolę, co widać na przykładzie kar hańbiących (a więc pozbawiających honoru $)^{38}$. Montaigne wskazywał na antagonizm między oficjalną

33 P. Bourdieu, op. cit., s. 200-201.

${ }^{34}$ K. Simon-Muscheid, op. cit., s. 18.

${ }^{35}$ N. Starczenko, Zapowiedź zemsty na Wołyniu w 2. połowie XVI - na początku XVII wieku, „Barok” 18, 2011, 1, s. 283-312.

${ }^{36}$ P. Schuster, Ehre und Recht. Überlegungen zu einer Begriffs- und Sozialgeschichte zweier Grundbegriffe der mittelalterlichen Gesellschaft, w: Ehrkonzepte in der Frühen Neuzeit, s. 56-57.

37 Ibidem, s. 54.

38 Więcej na ten temat: G. Schwerhoff, Verordnete Schande? Spätmittelalterliche und frühneuzeitliche Ehrenstrafen zwischen Rechtsakt und sozialer Sanktion, w: Mit den Waffen der Justiz. Zur Kriminalitätsgeschichte des Spätmittelalters und der Frühen Neuzeit, red. A. Blauert, 
jurysdykcją a szlacheckim (honorowym) rozumieniem praworządności, którego przyczyną miały być „podwójne prawa, prawa honoru i prawa sprawiedliwości, w niektórych rzeczach cale sprzeczne. Tak samo surowo jedne potępiają na przykład, gdy ktoś zostawi zadanie łgarstwa bez pomsty, jak drugie karzą pomstę, którą sobie weźmie"39. Problem dwusystemowości można rozważyć także pod nieco innym kątem - konfliktu między zasadami honorowymi a wartościami chrześcijańskimi. Historiografia niemiecka przyjmuje, że honor był nadrzędną wartością w kulturze ludów germańskich, czego liczne ślady znajdujemy choćby w sagach. Dopiero z czasem, w wiekach średnich, miało dojść do częściowego połączenia pogańskiej idei honoru z podejściem chrześcijańskim, w którym honor miał wyrażać bojaźń przed Bogiem i szacunek do niego ${ }^{40}$. Niektóre wymogi honoru, takie jak prawdomówność czy dotrzymywanie obietnic, były zgodne z nauką Kościoła, niektóre jednak, na przykład zemsta, całkowicie sprzeczne. Funkcjonowanie w ramach obu różnych kodeksów postępowania jednocześnie mogło być dla jednostki źródłem frustracji i wewnętrznego rozdarcia. Owo napięcie było częstym tematem nowożytnego dramatu, czego najlepszym przykładem jest Hamlet, w którym bohater stoi przed obowiązkiem walki o honor (pomszczenia ojca) z perspektywą potępienia ${ }^{41}$.

Honor można analizować także jako kod zachowania. Słowa, mimika, gesty przekazywały informacje o nim, często w wymiarze symbolicznym. Ukłon, pozdrowienie, zdjęcie nakrycia głowy były wyrazem honoru wobec drugiej strony. Sytuacją odmienną były walki czeladników o honor swoich cechów, podczas których wykrzykiwali o przeciwnikach obelżywe przyśpiewki i wykonywali prowokacyjne ruchy, np. uderzenia w szyję. Rekonstrukcja gestów pokazuje rangę cielesnej komunikacji w epoce, w tym wymowę poszczególnych części ciała ${ }^{42}$.

Omawiając kategorię honoru w społeczeństwie nowożytnym, nie można pominąć różnic wynikających z płci. Dawniej, tak jak i dzisiaj,

G. Schwerhoff, Frankfurt a. M. 1993, s. 158-188; R. van Dülmen, Theater des Schreckens. Gerichtspraxis und Strafrituale in der Frühen Neuzeit, Monachium 1988; V. Groebner, Das Gesicht wahren. Abgeschnittene Nasen, abgeschnittene Ehre in der spätmittelalterlichen Stadt, w: Verletzte Ehre, s. 361-380.

39 M. Montaigne, Próby, tłum. T. Boy-Żeleński, Warszawa 1957, s. 71.

${ }^{40}$ K. Zunkel, Ehre, w: Geschichtliche Grundbegriffe. Historisches Lexikon zur politischsozialen Sprache in Deutschland, red. O. Brunner, W. Conze, R. Koselleck, t. 2: E-G, Stuttgart 1992, s. 2-6.

${ }^{41}$ B. Joseph, Conscience and the King, London 1953, za: C.L. Barber, op. cit., s. 34.

${ }^{42}$ M. Dinges, Die Ehre als Thema der historischen Anthropologie. Bemerkungen zur Wissenschaftsgeschichte und zur Konzeptualisierung, w: Verletzte Ehre, s. 53; K. Simon-Muscheid, op. cit., s. 16-17. 
poniżające określenia kobiet były silnie związane ze sferą seksualną. Podczas gdy mężczyzna mógł być określany szelmą, złodziejem, łajdakiem, kobietę niemal zawsze wyzywano od dziwki (kurwy). Różnica ta wynikała z odmiennych ról społecznych - mężczyzna był aktywny w wielu dziedzinach życia, przede wszystkim w działalności zawodowej, której tak często dotyczyły wszelkie zniesławienia, a także sprawując różne funkcje w sferze publicznej, co wymagało nienagannej opinii i zaufania społecznego. Natomiast role społeczne kobiety opierały się w dużej mierze na jej relacjach seksualnych z płcią przeciwną (panna, żona, wdowa), a jej tożsamość była określana poprzez działalność jej ojca lub męża (córka pastora, sołtysowa, wdowa po mistrzu cechowym). Męski i żeński honor były ze sobą ściśle splecione, bo nadszarpnięcie honoru kobiety wpływało na reputację całego domu ${ }^{43}$. Co więcej, często znieważenie kobiety było wymierzone tak naprawdę w jej męża - w ten sposób na przykład można było łatwo osłabić konkurenta w ubieganiu się o pożądane stanowisko (poprzez naznaczenie go jako „rogacza”). Zachowanie córek i żon musiało być więc ciągle poddawane kontroli, by rodzina nie odniosła strat. Warto przy okazji wspomnieć o różnicy w zachowaniach honorowych między północną a południową Europą (podobnie w przypadku Ameryki). Stawiane są tezy, że w społeczeństwach południowych kobiety broniły swego honoru poprzez mężczyzn - zachęcały ich do zemsty w ich imieniu. Na północy z kolei miały być bardziej aktywne i często same walczyły o swój honor ${ }^{44}$.

Powyższe rozważania prowadzą do zasadniczego wniosku - honor jednostki nierozerwalnie wiązał się z honorem grupy. Czy była to rodzina, gildia kupiecka, czy bractwo religijne, podważenie honoru jednostki zagrażało nie tylko jej bytowi, ale i pomyślności osób z nią związanych. Jeśli pracownik zakładu miał opinię niehonorowego, sprzedaż wyrobów mogła znacznie spaść, a panna, która straciła honor, utrudniała dobre zamążpójście także swoim siostrom. Ogromną rolę odgrywało poczucie grupowej tożsamości, na przykład zelżenie kogoś od „papieskiego szelmy" mogło dotknąć wszystkich okolicznych katolików, szczególnie jeśli byli w mniejszości. Podobnie było, gdy zaatakowano osobę podwładną - szlachcic mógł poczuć się zraniony na honorze, gdy zaatakowano poddanych mu chłopów lub mieszczan ${ }^{45}$. Urażenie czyjegoś honoru

${ }^{43}$ M. Dinges, Ehre und Geschlecht in der Frühen Neuzeit, w: Ehrkonzepte in der Frühen Neuzeit, s. 132.

${ }^{44}$ Ibidem, s. 145; idem, Die Ehre als Thema der historischen Anthropologie, s. 54-55; J. Pitt-Rivers, op. cit., s. 19-78.

${ }_{45}$ M. Sawicki, Honor w mentalności szlachty województwa mińskiego w czasach saskich, w świetle korespondencji, „Wschodni Rocznik Humanistyczny” 4, 2007, s. 146. 
niosło za sobą konflikt z jego otoczeniem, stąd liczne walki cechowe, niesnaski klanowe, tumulty. Mowa więc o fenomenie wielopoziomowym, który mógł dotyczyć zarówno jednostki, jak i grup, także na poziomie makro - mamy przecież honor miast, krajów, narodów.

W polskiej historiografii honor, jeśli w ogóle staje się przedmiotem rozważań, to przedstawiany jest niemal wyłącznie jako przymiot elitarnych grup społecznych. W dosłownie kilku publikacjach zauważono range honoru również w społecznościach wiejskich, nie podjęto się jednak rozwinięcia tego tematu ${ }^{46}$. W nielicznych pracach poświęconych staropolskiej mentalności pojawiają się twierdzenia o wysokiej pozycji honoru w ówczesnej hierarchii wartości, nie pokuszono się jednak o pogłębioną refleksję na temat tego zjawiska, także w szerszej, międzystanowej, perspektywie $^{47}$. Wydaje się, że wynika to $\mathrm{w}$ dużej mierze $\mathrm{z}$ przejmowania wyłącznie szlacheckiego punktu widzenia, a w konsekwencji z przypisywania kategorii honoru tylko stanowi szlacheckiemu. Nie ma ku temu jednak wystarczających podstaw. Powtórzmy raz jeszcze, że koncepcja honoru występowała we wszystkich grupach społecznych, także wśród ludzi marginesu - przecież kaci, złodzieje, prostytutki także mieli swoje kodeksy honorowe ${ }^{48}$. Po raz kolejny zacytujmy Schopenhauera: „Cześć mieszczańska bierze wprawdzie miano od stanu mieszczańskiego, obowiązuje jednak we wszystkich stanach bez różnicy, nie wyłączając nawet najniżej położonych; nikt nie może się bez niej obyć, jest to dla każdego sprawa wyjątkowo poważna i należy wystrzegać się, by jej nie zlekceważyć" ${ }^{49}$. Odmienne było natomiast to, co honorowość danej jednostki bądź grupy konstytuowało. Przyjmując, że honor zależał od stosowania się do obowiązujących dla danej grupy społecznej norm - etosu grupowego, różnice przebiegały tam, gdzie owe normy się zmieniały - czym innym był honor dla kobiety, czym innym dla mężczyzny, inne zasady honorowe obowiązywały szlachtę, inne mieszczaństwo. Nic nie wskazuje na

${ }^{46} \mathrm{P}$. Kitowski, Zarzut czarostwa jako kalumnia $w$ praktyce sądowej mniejszego miasta pomorskiego $w$ drugiej połowie XVII i XVIII wieku, ZH 81, 2016, 3, s. 59-72; S. Achremczyk, Samorzad chłopski na Żuławach Malborskich w XVI-XVIII wieku, w: Samorzady i reprezentacje chłopskie w Europie pótnocnej u progu nowożytności (XV-XVIII wiek), red. A. Czacharowski, Toruń 1990.

47 M. Sawicki, op. cit., s. 141-153; A. Sowa, Świat ministrów Augusta II. Wartości i poglądy funkcjonujące $w$ kręgu ministrów Rzeczypospolitej w latach 1702-1728, Kraków 1995 (Bibliotheca Iagiellonica. Fontes et Studia, t. 3), s. 41-43; I. Kotowicz-Borowy, Honor to nie tylko słowo. Studium tożsamości kulturowej drobnej szlachty pótnocnego Mazowsza, Pułtusk 2005; w kontekście europejskim: M. Ossowska, Ethos rycerski i jego odmiany, Warszawa 1973.

${ }^{48}$ M. Dinges, Die Ehre als Thema der historischen Anthropologie, s. 30-31.

49 A. Schopenhauer, op. cit., s. 456. 
to, by i chłopi nie mieli mieć honoru, wręcz przeciwnie, dotychczasowe badania wykazały analogie do wyższych stanów ${ }^{50}$. Jak pisał Friedrich von Logau, niemiecki poeta barokowy ze Śląska: „Wehr-, lehr-, nähr-stand, ieder stand hat sein eignes ehr in sich" („Stan broniący, modlący się, robiący - każdy ma swój własny honor") ${ }^{51}$. Zresztą kategoria stanu nie wystarczy do zrozumienia omawianego zjawiska, należałoby raczej przyjrzeć się specyfice poszczególnych grup społecznych i ich etosów. Inne zasady honorowe obowiązywały bowiem na przykład ogrodników, a inne hodowców bydła - dla pierwszych zranieniem honoru było zniszczenie drzewa owocowego, dla drugich kradzież krowy ${ }^{52}$. Georg Simmel wprowadził pojęcie honoru „ujemnego” i „pozytywnego” - poszczególne grupy społeczne zawieszają niektóre z ogólnych norm honorowych i dodają własne wymagania. W ten sposób grupy przestępcze mogą stosować pewne praktyki powszechnie uchodzące za niehonorowe i pozostać (przynajmniej we własnym kręgu) osobami honorowymi ${ }^{53}$.

Wątpliwości co do obowiązywania kategorii honoru wśród wszystkich stanów z pewnością nie miał Antoni Sebastian Dembowski, biskup płocki i kujawski, który napisał satyrę pod znamiennym tytułem Punkt Honoru wydaną drukiem w 1749 r. Honor jest w oczach Dembowskiego demonem, który opanował całe społeczeństwo, bez różnicy: kobiety i mężczyzn, młodych i starych, prostych i wykształconych, czeladników i patrycjuszy, chłopów, szlachciców i zakonników. Wszystkie te grupy łączy właśnie honor, a właściwie wrażliwość na jego punkcie, co prowadzi do ciągłych awantur i eskalacji przemocy, a w konsekwencji do społecznej dezintegracji. Narrator napotyka na swojej drodze kolejne

50 B. Müller-Wirthmann, Raufhändel. Gewalt und Ehre im Dorf, w: Kultur der einfachen Leute. Bayerisches Volksleben vom 16. bis zum 19. Jahrhundert, red. R. van Dülmen, München 1983, s. 79-111; W. Rummel, Verletzung von Körper, Ehre und Eigentum. Varianten im Umgang mit Gewalt in Dörfern des 17. Jahrhunderts, w: Mit den Waffen der Justiz, s. 86-114; M. Frank, Dörfliche Gesellschaft und Kriminalität. Das Fallbeispiel Lippe (1650-1800), Paderborn 1995; idem, Ehre und Gewalt im Dorf der Frühen Neuzeit. Das Beispiel Heiden (Grafschaft Lippe) im 17. und 18. Jahrhundert, w: Verletzte Ehre, s. 320-338; M. Toch, Schimpfwörter im Dorf des Spätmittelalters, „Mitteilungen des Instituts für Österreichische Geschichtsforschung” 101, 1993, 2, s. 311-327; R. Walz, Agonale Kommunikation im Dorf der Frühen Neuzeit, „Westfälische Forschungen" 42, 1992, s. 215-251; idem, Der Hexenwahn vor dem Hintergrund dörflicher Kommunikation, „Zeitschrift für Volkskunde” 82, 1986, s. 1-18; idem, Schimpfende Weiber. Frauen in lippischen Beleidigungsprozessen des 17. Jahrhunderts, w: Weiber, Menscher, Frauenzimmer. Frauen in der ländlichen Gesellschaft, 1500-1800, red. C. Vanja, H. Wunder, Göttingen 1996, s. 175-198.

${ }^{51}$ K. von Logau, Sinngedichte, cyt. za: D. Burkhart, Eine Geschichte der Ehre, Darmstadt 2006, s. 36.

${ }^{52}$ M. Dinges, Die Ehre als Thema der historischen Anthropologie, s. 48-49.

53 G. Simmel, op. cit., s. 338-339. 
sytuacje, w których honor jest główną motywacją ludzkiego działania. Pierwszą zresztą opisaną grupą są właśnie chłopi, którzy z powodu nadszarpniętego honoru pobili się w karczmie.

Powyższe rozważania teoretyczne warto uzupełnić przykładową analizą tekstów źródłowych, dowodzącą roli honoru w życiu społecznym wsi XVI-XVII w. Wybrany teren obejmuje osady Pomorza Gdańskiego, a dokładniej Mierzei Wiślanej i rozlewisk rzeki Szkarpawy (Wisły Elbląskiej), znajdujące się pod jurysdykcją gdańskiej rady miejskiej. Sytuacja prawna tamtejszych chłopów była lepsza od tej obowiązującej zazwyczaj na pozostałych ziemiach Rzeczypospolitej, dość powiedzieć, że nie obejmowała ich pańszczyzna, a jedynie czynsz i prace szarwarkowe (w tym wymagające dużego wysiłku roboty przy wałach przeciwpowodziowych). Wraz z sukcesem reformacji w Gdańsku luteranizm przyjęli również mieszkańcy należących do miasta wsi. Większość osadników pochodziła z niemieckiego kręgu językowego, skład etniczny nie był jednak homogeniczny - przybywało tu niemało osób pochodzenia szkockiego, holenderskiego, kaszubskiego i pomorskiego. Gospodarka rolna nie była jedynym źródłem utrzymania mieszkańców Mierzei z powodu dużego zapiaszczenia półwyspu. Nie ziemia, a woda była żywiołem, z którym na co dzień zmagali się miejscowi - istotnym źródłem pozyskiwania pożywienia było rybołówstwo, a nieuregulowany bieg licznych odnóg Wisły stanowił ciągłe zagrożenie dla bytu pobliskich osad.

W badanych kazusach stronami procesowymi są głównie lokalni chłopi, często należący do wiejskiej elity - karczmarze, sołtysi i gospodarze. Dość liczną grupę, szczególnie aktywną w sytuacjach z użyciem przemocy, stanowią także parobcy, w przeciwieństwie do żeńskiej służby wiejskiej, która tylko wyjątkowo występuje jako strona procesowa. Ogółem kobiety brały udział w sprawach sądowych w ok. 35 proc. przypadków, zazwyczaj jako poszkodowane. Egzemplifikacje pochodzą z akt sądowych Mierzei (Nehrung) i Szkarpawy (Scharpau) przechowywanych w Archiwum Państwowym w Gdańsku pod sygnaturami: 300,2/1-300,2/7. W księgach tych znajdują się zapisy rozpraw toczonych przed sądem burmistrzowskim w Sztutowie (Stutthofie), będącym drugą instancją po sądach sołtysich. W dokumentach z okresu 1582-1605 znaleziono ponad 200 spraw, w których honor odgrywał kluczową rolę. W przeważającej liczbie są to oskarżenia o znieważenia, plotki, oszczerstwa, często z użyciem przemocy fizycznej, do tego kilkanaście oskarżeń o nadużycia seksualne.

Aby uchwycić problem honoru w badanych sprawach, należy zacząć od ich zakończenia. $Z$ reguły rozpatrywane procesy kończyły się $\mathrm{w}$ taki sam sposób - zapewnieniem pozwanego, iż o powodzie „nie wie nic 
niehonorowego, lecz to, co przystoi honorowi" 54 . Cechą charakterystyczną tego typu spraw były relatywnie niskie kary, a i to głównie pieniężne (wyższe w przypadku trwałego uszczerbku na zdrowiu oraz ataku na urzędnika) lub w ogóle ich całkowity brak. Celem procesu nie była bowiem kara, lecz przywrócenie ofierze poważania i należnego jej miejsca w społeczności. Po wypowiedzeniu standardowej formuły przez oskarżonego, sąd oficjalnie zwracał honor poszkodowanej stronie, formuła brzmiała: ,jej honor jest jej w pełni zwrócony, i to, co się wydarzyło, nie przynosi szkody jej honorowi" ${ }^{55}$ lub „honor i dobre imię powinny być w pełni nienaganne i bez winy" ${ }^{26}$. Nieraz także i w treści oskarżenia pojawiały się słowa o honorze, o tym, że został on zraniony (verletzet) lub dotknięty (betastet). Niejaka Gerde oskarżyła Szkota Hansa Metzkego o to, że rozpowiadał między ludźmi jakoby mieli żyć w związku nieformalnym przez wiele lat, przez co „ściągnął na nią krzyk i niezawinione podejrzenie" 57 . Metzke ,jej honor ogromnie nadwyrężył, samego siebie okrywając hańbą i do tego rozpowiedział to między ludzi" ${ }^{58}$. Wieś huczała od plotek, które dotarły także do uszu miejscowego pastora. Wytykana palcami Gerde utraciła swój status społeczny, i tak niski w przypadku niezamężnej kobiety. Jako powód wniesienia oskarżenia podała dosłownie „zranienie honoru, dyfamację i zhańbienie honoru” 59 . Honor był świadectwem życia według społecznych reguł, bez jego przywrócenia poszkodowana nie mogła być więc pełnoprawną członkinią społeczności. Sprawa określona jako „poważne znieważenie” zakończyła się wyjątkowo surowym wyrokiem - trzema miesiącami więzienia. Na koniec postępowania burmistrz oficjalnie uwolnił skarżącą od wszelkich podejrzeń.

Każdy mieszkaniec wsi niezależnie od swojej pozycji mógł zostać w każdej chwili pozbawiony honoru i musiał liczyć się z bolesnymi tego konsekwencjami. Pewna chłopka zwyzywała sołtysa Tujska Salomona Vosa od „szelmy i złodzieja”, a także oświadczyła, że „nie jest on godzien pić piwo z honorowym człowiekiem”. W ten sposób został on naznaczony

54 „wiße ehr nichts unehrliches, sondern was den ehren gemeß” lub „vom kleger nichts anders den waß den ehren gemeß wisse zusagen”, AP w Gdańsku (dalej: APG), sygn. $300,2 / 1$, k. 50 .

55 „ihrer ehren vollen kommen wieder ersetzet, und sol solches, was etwan geschehen, ihren ehren unschendlich sein", APG, sygn. 300,2/6, k. 213v.

56 „seinen ehren und guten nahmen gantz unschuldlich und unverweislich sein solle", APG, sygn. 300,2/7, k. 150.

57 „ins geschrei und unschuldige Verdacht gebracht”, APG, sygn. 300,2/7, k. 141v.

58 „sie an ehren gröblich zubetasten, seine eigene schande namkundigk zumachen, und die damit unter die Leute zubringen sich unterstanden", ibidem.

59 „solcher ehren verletzunge, an der Diffamanten und ehrschandernn”, APG, sygn. $300,2 / 7$, k. 125v-126. 
i symbolicznie wyłączony ze społeczności. Co więcej, ponoć miał niedługo zostać zdjęty z urzędu. Pod wypowiedzią kobiety mogła się więc kryć zachęta do nieposłuszeństwa wobec sołtysa. Przez to „oczernianie, znieważanie i zniesławianie” Vos stracił narzeczoną, choć tu duże znaczenie mogło mieć także pomówienie o chorobę weneryczną („francę"). Publiczna wypowiedź odzierająca kogoś z honoru w krótkim czasie mogła zrzucić go z góry na sam dół hierarchii społecznej ${ }^{60}$.

Skoro pozbawienie honoru stanowiło tak duże niebezpieczeństwo, należało na nie jak najszybciej odpowiedzieć. Część z pomówionych próbowała się oczyścić przed sądem, jednak wielu reagowało w sposób bardziej bezpośredni i, co ważne, natychmiastowy - stosując przemoc fizyczną. Można zaryzykować twierdzenie, że uderzenie oszczercy było odebraniem wiarygodności jego słowom i zademonstrowaniem własnej pozycji. Wydaje się, że pobicie kogoś za szkodę na honorze było powszechnie stosowaną praktyką, choć łączyło się to z ryzykiem odpowiedzialności karnej. Mimo że większość tego typu spraw dotyczyła drobnych pobić, czasem dochodziło do prawdziwych awantur, szczególnie gdy okoliczności temu sprzyjały (przyjęcia, święta). Taka sytuacja miała miejsce na pewnym weselu w Kaltenherberge (dziś Krynicy Morskiej) w 1605 r. Jeden z gości - Michel Tilke z Babke (dziś Rybiny), rzucił niejakiemu Tomasowi Löbenerowi wyzwanie, kładąc przed nim na stół uzdę jego (Löbenera) konia. Choć trudno mówić w kulturze chłopskiej o tak sformalizowanym rytuale pojedynkowania się jak u szlachty, to pewne podstawowe elementy, jak rzucenie wyzwania i reakcja na nie w formie walki, są analogiczne. Najpierw jednak musiała nastąpić odpowiedź ustna w postaci obrażenia przeciwnika i pozbawienia go honoru. Löbener wstał i powiedział, że „tego nie zrobił honorowy, lecz szelma i złodziej". Co więcej, znieważanie zostało skierowane nie tylko do głównego winowajcy, lecz do całej jego grupy - wszystkich mieszkańców Babke obecnych na weselu, Löbener dodał bowiem: „tego nie uczynił nikt inny jak szelmowscy Babkowianie" ${ }^{61}$. Wyzwanie dotknęło więc nie

60 „sie durch ihr affterreden, Iniurien und diffamiren verursachet, das ihm seine braut abspehnigk und wiederumb auffgesaget worden, in dem sie ihn hinterrucks, offentlich fur einen schelm und dieb, und der nicht wirdigk were mit einem ehrlichen menschen eine kanne bier zutrincken, ia der wirdigk were, das er seines ambtes entsetzet wurde, hette ihn auch ausggeschalliret, als wen er die frantzosen hette", APG, sygn. $300,2 / 9$, k. $45 \mathrm{v}$.

61 „der Tomas Löbener auffgestanden, und hette gesprochen, das hat kein ehrlicher, sondern ein Schelm und dieb gethan, welcher einem sein pferd auszeumen darff, ia ferner gesaget, dies hat niemand anders, den die schelmeschen Babekere gethan", APG, sygn. $300,2 / 9$, k. 181. 
jednostki, lecz grupy ludzi - do obrony honoru właściciela uzdy poczuli się także wszyscy jego kompani i w izbie podniósł się tumult. Nastąpił taki chaos, że z relacji świadków trudno odtworzyć dokładny przebieg bójki, w każdym razie w ruch poszły wszystkie przedmioty, jakie goście mieli pod ręką - noże, dzbany oraz garnki, do tego rwano ubrania i rzucano ławami. Tilke, wielokrotnie raniony, ponoć ledwo umknął śmierci ${ }^{62}$.

Tłem spraw o honor bardzo często były konflikty sąsiedzkie i rywalizacja gospodarcza. Jak już wspomniano, podważenie honoru przeciwnika, a więc odebranie mu swoistej gwarancji uczciwości, było najprostszym sposobem pozbycia się konkurencji. Takim przypadkiem był spór o prowadzenie wyszynku piwa między karczmarzem Gregerem Ebelerem alias Sachse a Michelem Stegemanem, przedstawicielem wiejskiego samorządu. Ten ostatni, ewidentnie mający zakusy na karczmę, próbował podważyć dobrą opinię o gospodarzu, mówiąc, że „wszystko co ma, przywłaszczył sobie kłamaniem i zwodzeniem" oraz poddając w wątpliwość jego prawe urodzenie. Słowa te określono jako „znieważenie, despekt i umniejszenie”, które „ciążą na jego [Ebelera] honorze”. Co prawda oskarżony podkreślił w czasie rozprawy sądowej, że o honorze karczmarza nie może się źle wyrazić, ale zaraz potem zaczął wytykać mu przed sądem szynkowanie „złego piwa"63. O tym, że podważanie honoru rywali było skuteczną strategią zwiększania przewagi konkurencyjnej na rynku, najlepiej świadczy zakończenie omawianej sprawy. Kilka miesięcy później Stegeman otrzymał bowiem prawo do wyłącznego wyszynku piwa na terenie wsi na roczny okres próbny. Niezależnie od tego, czy Sachse rzeczywiście obniżał jakość trunku, zakwestionowanie jego pochodzenia i inne działania szkodzące jego wizerunkowi (honorowi) pozwoliły podważyć zaufanie całego środowiska, w tym władz, i w konsekwencji wygrać rywalowi.

Podobnie napięte stosunki musiały istnieć między Orbanem Lutkemanem, gospodarzem i witrykiem w Kobbelgrube (dziś na terenie Stegny), a panem Lorensem, pastorem tamże. Prawdopodobnie w grę wchodził spór konfesyjny, ponieważ kaznodzieja zarzucił mężczyźnie „niewierność

${ }^{62}$ APG, sygn. 300,2/7, k. 177v-178v, 180v-182v, 184-186.

63 „2. Habe ihm Beklagter unterm gesichte gesagt, das er kleger, alles das ienige, was er habe, mit liegen und trigen an sich gebracht. 3. Haber ihn Beklagter, wegen seiner geburt gerechtfertiget, und zuwißen begeret, wo er seinen geburts brieff hette? 4. Da er kleger ihm drauff gefraget, was er, mangels an seiner geburt hette, und was er ihm fur unehrliche Thaten wuste nachzusagen, Habe Beklagter zu unterschiedlichen malen geandwordtet, er Wuste ihm keine ehre nachzusagen. Wan ihm dan, ehren halben obliege, sich der beigemeßenen Iniurien, despects und Verkleinerunge, zuverandwordten, auch seine habende gerechtigkeit im krugkwergke, zuvertreten", APG, sygn. 300,2/5, k. 186. 
kościołowi i wiele innych raniących słów na niego wylał”, żadne szczegóły nie zostały jednak ujawnione. Lutkeman skarżył się przed sądem, że został przez Lorensa „poważnie zraniony na honorze”. Co jednak szczególnie istotne, zrobił to podczas nabożeństwa, „,nie tylko przy innych ludziach, ale publicznie, z kazalnicy". Lutkeman uzasadnił wniesienie oskarżenia tym, że ,jako miłujący honor nie mógł tego zaniechać”. Honor to dobro, które było ustanawiane zewnętrznie, stąd oczernienie przed całą parafią musiało być szczególnie dotkliwe, i tak też opowiadał o tym sam poszkodowany. Jego skarga miała wręcz emocjonalny charakter, na przykład gdy mówił o tym, jak oszczerstwa kaznodziei „boleśnie nim wzruszyły”64. Analizując strategie społeczno-ekonomiczne i publiczny aspekt honoru nie należy zapominać wszak o jego emocjonalnym wymiarze. Przypomnijmy na koniec tezę Schopenhauera z początku naszych rozważań, że honor był jednym z najważniejszych elementów tożsamości człowieka.

Powyższe przykłady miały na celu na celu przedstawienie możliwości analizy zjawiska honoru i pokazanie, jak można używać tej kategorii w badaniach historycznych; nie wyczerpują one jednak sposobów interpretacji honoru, ani nie muszą być reprezentatywne dla całego regionu w danym czasie. Omawiany obszar był pod wieloma względami odmienny od pozostałych ziem Rzeczypospolitej, są jednak podstawy, by twierdzić, że analizowane zjawisko miało charakter powszechny, oczywiście z uwzględnieniem lokalnych uwarunkowań. Znawca polskiej wsi nowożytnej, Tomasz Wiślicz, zasygnalizował problem honoru w kontekście wyboru wiejskich władz samorządowych. Kandydat na wójta „na swej sławie naruszony" musiał zostać publicznie oczyszczony z zarzutów, aby móc sprawować ten urząd ${ }^{65}$. Stąd potrzeba dalszych badań, w tym porównawczych, odwołujących się także do specyfiki kulturowej Europy Środkowej i Wschodniej.

Prezentowane przemyślenia teoretyczne oraz przykłady źródłowe miały wykazać, że poczucie honoru przenikało całe nowożytne

64 „was mahssen er an ehr undt glimpff, groblich vorsehre worden, durch ihres dorffs Predigern hern Lorens, welcher nicht alleine bey anderen leutten, sonder auch offentlich auff der kantzel, ihnen untreuheidt bey der kirchen beschüldiget, undt etliche andere mehr vorsehrliche wortte über ihnen ausgegossen, die er sich schmertzlich zu gemütte führen thette, undt wie ein ehrliebender auff sich nicht woltte beruchen lassen", APG, sygn. 300,2/2, k. 20v-21.

${ }^{65}$ T. Wiślicz, Afera Tomasza Kobcza, czyli o samorzadności chłopów na wsi przedrozbiorowej, w: W podróży przez wiek osiemnasty... Studia i szkice z epoki nowożytnej, red. A. Perłakowski, M. Wyszomirska, M. Zwierzykowski, Kraków 2015, s. 197-211. Szczególnie intrygujące jest podobieństwo formuły zwracającej honor do tej występującej w omawianych wcześniej księgach Mierzei i Szkarpawy: ,jako żyw nic nie wie, jedno wszystko dobre, a jeśli kiedy co mówił z głupstwa, tedy to wyznawa, iż niesłusznie mówił”, ibidem, s. 204. 
społeczeństwo, od warstw najniższych do najwyższych. Oznaczał on wartość człowieka jako jednostki społecznej i był podstawą jego funkcjonowania w społeczeństwie. Było to pokłosiem wysokiego poziomu kolektywizmu europejskiego społeczeństwa, gdzie tożsamość jednostki konstytuowana była zewnętrznie, poprzez innych członków zbiorowości. Zjawisko to miało także wymiar ekonomiczny - posiadanie honoru przekładało się na możliwości wymiany handlowej, pełnienia urzędów, nawiązywania relacji biznesowych, zawierania małżeństw. To dlatego dokładano wszelkich starań, by honor swój i swojej grupy zachować. A stracić było go bardzo łatwo - wystarczyło, że jeden z członków społeczności poddał w wątpliwość honorowe, to jest zgodne ze społecznymi normami, postępowanie jednostki (ewentualnie grupy). Honoru należało nieustannie bronić, co prowadziło do stanu ciągłego zagrożenia i walki. Stąd można zauważyć ścisły związek między honorem a przemocą. Obowiązek walki o honor dotyczył w takim samym stopniu prostego rzemieślnika, jak i szlachcica, choć oczywiście jej reguły były odmienne, jak odmienne były etosy grup, do których należeli. Mimo że honor był kategorią uniwersalną, każda grupa społeczna wypracowywała inne normy honorowego postępowania, w zależności od właściwego sobie etosu. Różnice nie przebiegały jednak tylko według stanów i zawodów równie istotne były te wynikające z płci czy stanu cywilnego. Honor był podstawą tożsamości jednostki oraz grupy, a także jednym z głównych czynników kształtujących relacje społeczne, polityczne i ekonomiczne.

Jednym z założeń niniejszego artykułu było przedstawienie różnych punktów widzenia kategorii honoru. Można go uznać za statyczną właściwość przypisywaną komuś z racji przynależności do określonej grupy społecznej bądź przyjąć, że jest on wynikiem działania podmiotu, który spełnia oczekiwania zbiorowości i dzięki temu otrzymuje zdolność honorową. Można twierdzić, że jest on konstruowany zewnętrznie, na przykład poprzez podarunki, godności, urzędy, lub położyć nacisk na wewnętrzny jego wymiar, oparty na przekonaniu jednostki o swojej własnej wartości. Wreszcie można postrzegać honor jako kategorię podzielaną jedynie przez jedną grupę, na zasadzie odróżnienia się od innych, albo dostrzec, że dotyczy ona ogółu społeczeństwa. Honor może dotyczyć jednostek lub grup, przybrać postać materialną i niematerialną, można go stracić oraz zyskać. Czy przyjmiemy koncepcję honoru jako kapitału, kodu zachowania, medium społecznej interakcji, alternatywnego systemu norm, elementu kolektywnej lub indywidualnej tożsamości, czy zdefiniujemy ją w jeszcze inny sposób, wzbogacimy analizę dawnego społeczeństwa i być może zmienimy także postrzeganie niższych grup społecznych. 


\section{Streszczenie}

Kategoria honoru, szczególnie w odniesieniu do niższych warstw społecznych, nie była do tej pory przedmiotem refleksji polskiej historiografii. Niniejszy artykuł zmierza do odpowiedzi na pytania o znaczenie honoru i możliwe sposoby jego interpretacji, a także o przydatność tej kategorii w badaniach historycznych. Wykorzystano przy tym klasyczne teorie na ten temat z zakresu historii, socjologii, filozofii i antropologii. Refleksje teoretyczne zostały uzupełnione analizą wiejskich ksiąg sądowych z terenu Mierzei Wiślanej z przełomu XVI/XVII w. Przekazy źródłowe potwierdzają szczególną pozycję honoru w chłopskiej hierarchii wartości, a także jego przemożny wpływ na relacje społeczno-gospodarcze wsi. Honor nie był jedynie domeną stanu szlacheckiego, lecz kompleksowym systemem reguł, kształtującym życie wszystkich grup społecznych.

\section{Did the Peasant Have Honour? The Use of Category of Honour in Studies into Early Modern Society}

The category of honour, especially in reference to lower social strata, has not yet been the subject of reflection of Polish researchers. The present article seeks to answer the questions about the meaning of honour and its possible interpretations, together with that about the usefulness of this category in historical studies. To this end, classic historical, social, philosophical, and anthropological theories are used. The theoretical reflections are reinforced with an analysis of village court registers from the area of the Vistula Spit at the turn of the seventeenth century. The source evidence proves the special role of honour in the peasant hierarchy of values, and its great impact on rural socio-economic relations. Honour therefore was by no means solely the domain of the nobility, and operated though a complex system of rules shaping the life of all social classes.

Translated by Grażyna Waluga

\section{Bibliografia}

Achremczyk Stanisław, Samorzad chłopski na Żuławach Malborskich w XVI-XVIII wieku, w: Samorządy i reprezentacje chłopskie w Europie pótnocnej u progu nowożytności (XV-XVIII wiek), red. Antoni Czacharowski, UMK, Toruń 1990, s. 105-132.

Barber Charles Laurence, The Idea of Honour in the English Drama 1591-1700, Elanders, Göteborg 1957.

Bourdieu Pierre, The Sentiment of Honour in Kabyle Society, w: Honour and Shame. The Values of Mediterranean Society, red. John G. Peristany, Weidenfeld and Nicolson, Chicago 1970, wyd. 2 „The Nature of Human Society”, s. 191-241.

Burkhart Dagmar, Eine Geschichte der Ehre, Wissenschaftliche Buchgesellschaft, Darmstadt 2006. 
Die Ökonomie sozialer Beziehungen. Ressourcenbewirtschaftung als Geben, Nehmen, Investieren, Verschwenden, Haushalten, Horten, Vererben, Schulden, red. Gabriele Jancke, Daniel Schläppi, Franz Steiner, Stuttgart 2015.

Dinges Martin, Die Ehre als Thema der historischen Anthropologie. Bemerkungen zur Wissenschaftsgeschichte und zur Konzeptualisierung, w: Verletzte Ehre. Ehrkonflike in Gesellschaften des Mittelalters und der Frühen Neuzeit, red. Klaus Schreiner, Gerd Schwerhoff, Böhlau, Köln 1995, s. 29-62.

Dinges Martin, Die Ehre als Thema der Stadtgeschichte. Eine Semantik im Übergang vom Ancien Régime zur Moderne, „Zeitschrift für Historische Forschung” 16, 1989, 4, s. 409-440.

Dinges Martin, Ehre und Geschlecht in der Frühen Neuzeit, w: Ehrkonzepte in der Frühen Neuzeit. Identitäten und Abgrenzungen, red. Sibylle Backmann, Hans-Jörg Künast, Sabine Ullmann, B. Ann Tlusty, Akademie, Berlin 1998, s. 123-147 (Colloquia Augustana, t. 8).

Dülmen Richard van, Theater des Schreckens. Gerichtspraxis und Strafrituale in der Frühen Neuzeit, C.H. Beck, München 1988.

Elias Norbert, Die höfische Gesellschaft. Untersuchungen zur Soziologie des Königtums und der höfischen Aristokratie mit einer Einleitung. Soziologie und Geschichtswissenschaft, Darmstadt, Neuwied 1977.

Farge Arlette, Rodziny. Honor i sekret, w: Historia życia prywatnego, t. 3: Od renesansu do oświecenia, red. Roger Chartier, red. wyd. pol. Andrzej Łoś, Ossolineum, Wrocław, Warszawa, Kraków 2005, s. 663-705.

Fedyszak-Radziejowska Barbara, Etos pracy rolnika. Modele społeczne a rzeczywistość, Instytut Rozwoju Wsi i Rolnictwa PAN, Warszawa 1992.

Frank Michael, Dörfliche Gesellschaft und Kriminalität. Das Fallbeispiel Lippe (1650-1800), Schöningh, Paderborn 1995

Frank Michael, Ehre und Gewalt im Dorf der Frühen Neuzeit. Das Beispiel Heiden (Grafschaft Lippe) im 17. und 18. Jahrhundert, w: Verletzte Ehre. Ehrkonflike in Gesellschaften des Mittelalters und der Frühen Neuzeit, red. Klaus Schreiner, Gerd Schwerhoff, Böhlau, Köln 1995, s. 320-338

Groebner Valentin, Das Gesicht wahren. Abgeschnittene Nasen, abgeschnittene Ehre in der spätmittelalterlichen Stadt, w: Verletzte Ehre. Ehrkonflike in Gesellschaften des Mittelalters und der Frühen Neuzeit, red. Klaus Schreiner, Gerd Schwerhoff, Böhlau, Köln 1995, s. 361-380.

Joseph Bertram, Conscience and the King, a Study of Hamlet, Chatto and Windus, London 1953.

Kitowski Piotr, Zarzut czarostwa jako kalumnia w praktyce sądowej mniejszego miasta pomorskiego w drugiej połowie XVII i XVIII wieku, ZH 81, 2016, 3, s. 59-72.

Kotowicz-Borowy Irena, Honor to nie tylko słowo. Studium tożsamości kulturowej drobnej szlachty pótnocnego Mazowsza, Wyższa Szkoła Humanistyczna im. Aleksandra Gieysztora, Pułtusk 2005.

Kramer Karl S., Hohnsprake, Wrakworte, Nachschnack und Ungebühr. Ehrenhändel in holsteinischen Quellen, „Kieler Blätter zur Volkskunde” 16, 1984, s. 63-85.

Mahrburg Adam, Honor, w: Wielka encyklopedia powszechna ilustrowana, seria 1, t. 29-30, Warszawa 1902, s. 322.

Montaigne Michel de, Próby, t. 1, tłum. Tadeusz Boy-Żeleński, PIW, Warszawa 1957. 
Monteskiusz, O duchu praw, tłum. Tadeusz Boy-Żeleński, F. Hoesick, Warszawa 1927. Müller-Wirthmann Bernhard, Raufhändel. Gewalt und Ehre im Dorf, w: Kultur der einfachen Leute. Bayerisches Volksleben vom 16. bis zum 19. Jahrhundert, red. Richard van Dülmen, Beck, München 1983, s. 79-111.

Ossowska Maria, Ethos rycerski i jego odmiany, PWN, Warszawa 1973.

Pitt-Rivers Julian, Honour and Social Status, w: Honour and Shame. The Values of Mediterranean Society, red. John G. Peristany, Weidenfeld and Nicolson, Chicago 1970, wyd. 2 „The Nature of Human Society”, s. 21-77.

Rummel Walter, Verletzung von Körper, Ehre und Eigentum. Varianten im Umgang mit Gewalt in Dörfern des 17. Jahrhunderts, w: Mit den Waffen der Justiz. Zur Kriminalitätsgeschichte des späten Mittelalters und der Frühen Neuzeit, red. Andreas Blauert, Gerd Schwerhoff, Fischer Taschenbuch, Frankfurt a. M. 1993, s. 86-114.

Sawicki Marcin, Honor w mentalności szlachty województwa mińskiego w czasach saskich, w świetle korespondencji, „Wschodni Rocznik Humanistyczny” 4, 2007, s. 141-153.

Schopenhauer Arthur, W poszukiwaniu mądrości życia. Parerga i paralipomena, t. 1, tłum. Jan Garewicz, Antyk, Warszawa 2002.

Schuster Peter, Ehre und Recht. Überlegungen zu einer Begriffs- und Sozialgeschichte zweier Grundbegriffe der mittelalterlichen Gesellschaft, w: Ehrkonzepte in der Frühen Neuzeit. Identitäten und Abgrenzungen, red. Sibylle Backmann, Hans-Jörg Künast, Sabine Ullmann, B. Ann Tlusty, Akademie, Berlin 1998, s. 40-66 (Colloquia Augustana, t. 8).

Schwerhoff Gerd, Verordnete Schande? Spätmittelalterliche und frühneuzeitliche Ehrenstrafen zwischen Rechtsakt und sozialer Sanktion, w: Mit den Waffen der Justiz. Zur Kriminalitätsgeschichte des Spätmittelalters und der Frühen Neuzeit, red. Andreas Blauert, Gerd Schwerhoff, Fischer Taschenbuch, Frankfurt a. M. 1993, s. 158188.

Simmel Georg, Pisma socjologiczne, oprac. Heinz-Jürgen Dahme, Otthein Rammstedt, Oficyna Naukowa, Warszawa 2008.

Simon-Muscheid Katharina, Gewalt und Ehre im spätmittelalterlichen Handwerk am Beispiel Basels, „Zeitschrift für Historische Forschung” 18, 1991, 1, s. 1-31.

Sowa Andrzej, Świat ministrów Augusta II. Wartości i poglądy funkcjonujące w kręgu ministrów Rzeczypospolitej w latach 1702-1728, Księgarnia Akademicka, Kraków 1995 (Bibliotheca Iagiellonica. Fontes et Studia, t. 3).

Starczenko Natalia, Zapowiedź zemsty na Wołyniu w 2. połowie XVI - na początku XVII wieku, „Barok” 18, 2011, 1, s. 283-312.

Toch Michael, Schimpfwörter im Dorf des Spätmittelalters, „Mitteilungen des Instituts für Österreichische Geschichtsforschung" 101, 1993, 2, s. 311-327.

Verletzte Ehre. Ehrkonflike in Gesellschaften des Mittelalters und der Frühen Neuzeit, red. Klaus Schreiner, Gerd Schwerhoff, Böhlau, Köln 1995.

Waardt Hans de, Ehrenhändel, Gewalt und Liminalität: ein Konzeptualiesierungsvorschlag, w: Verletzte Ehre. Ehrkonflike in Gesellschaften des Mittelalters und der Frühen Neuzeit, red. Klaus Schreiner, Gerd Schwerhoff, Böhlau, Köln 1995, s. 303-319.

Walz Rainer, Agonale Kommunikation im Dorf der Frühen Neuzeit, „Westfälische Forschungen" 42, 1992, s. 215-251.

Walz Rainer, Der Hexenwahn vor dem Hintergrund dörflicher Kommunikation, „Zeitschrift für Volkskunde" 82, 1986, s. 1-18. 
Walz Rainer, Schimpfende Weiber. Frauen in lippischen Beleidigungsprozessen des 17. Jahrhunderts, w: Weiber, Menscher, Frauenzimmer. Frauen in der ländlichen Gesellschaft, 1500-1800, red. Christina Vanja, Heide Wunder, Vandenhoeck Ruprecht, Göttingen 1996, s. 175-198.

Weber Max, Gospodarka i społeczeństwo. Zarys socjologii rozumiejącej, PWN, Warszawa 2002

Wellmann Hans, Der historische Begriff der "Ehre" - sprachwissenschaftlich untersucht, w: Ehrkonzepte in der Frühen Neuzeit. Identitäten und Abgrenzungen, red. Sibylle Backmann, Hans-Jörg Künast, Sabine Ullmann, B. Ann Tlusty, Akademie, Berlin 1998 (Colloquia Augustana, t. 8).

Wiślicz Tomasz, Afera Tomasza Kobcza, czyli o samorzadności chtopów na wsi przedrozbiorowej, w: W podróży przez wiek osiemnasty... Studia i szkice z epoki nowożytnej, red. Adam Perłakowski, Monika Wyszomirska, Michał Zwierzykowski, Księgarnia Akademicka, Kraków 2015, s. 197-211.

Zunkel Friedrich, Ehre, w: Geschichtliche Grundbegriffe. Historisches Lexikon zur politisch-sozialen Sprache in Deutschland, red. Otto Brunner, Werner Conze, Reinhard Koselleck, t. 2: E-G, Klett-Cotta, Stuttgart 1975, s. 1-63.

Biog ram: Jaśmina Korczak-Siedlecka (Kurczewska), ukończyła magisterium z historii na Uniwersytecie Warszawskim, w latach 2014-2017 była zatrudniona jako pracownik naukowy w Geisteswissenschaftliches Zentrum Geschichte und Kultur Ostmitteleuropas (GWZO) w Lipsku; obecnie kończy pracę doktorską w Instytucie Historii PAN. Obszary zainteresowań: historia społeczna epoki nowożytnej, historia kobiet, antropologia historyczna; kontakt: jasmina.k.siedlecka@gmail.com. 